\title{
THE LEVEL OF VARIATION IN YIELD AND YIELD DETERMINING FACTORS AND THEIR RELATIONSHIP IN DIFFERENT HEVEA GENOTYPES.
}

\author{
E.S. Munasinghe \& A. Nugawela \\ Rubber Research Institute of Sri Lanka
}

Natural rubber produccd by Hevea brasiliensis Mucll. Arg. is an industrially important raw material for which demand continucs both locally and intcrnationally. It is produced from the latex extracted/tapped from the rubber tree.

In this study, variation in yicld and some yicld detcrmining factors, i.c. girth, depth of tapping cut, tapping height and tapping angle and their relationships were studied on three genotypes (cloncs) of Hevea PB 217, RRIC 117 and RRIC 102. Cloncs have been planted in 1988 in a commercial cslatc in Sri Lanka and tapping began in 1994. From cach clones, an area having $\mathrm{ca}$. 100 trees was selected for the study.

Yield measured as latex volume was found to be highly significant clonal character. Among the three clones tested, the highest mean latex volume per tree per tapping was recorded in RRIC 102 whilst the lowest in PB 217.

Further, a significant tree-to-trec variation in yicld within a clone was observed in all three clones. The maximum co-cfficient of variation was found in PB 217 while minimum was in RRIC 102. Yield varied through different ranges in each of the three clones and PB 217 had more low yiclding trees whilst RRIC 102 and RRIC 117 had more medium yiclding trees. Yicld determining factors i.c. girth, depth of tapping cut found to vary within a clone in all three clones. Further, they were significantly and positively correlated to the yicld. Tapping height and tapping angle also varied within a clone and they too contributed to the yield variation within a clone.

Out of the yield determining factors considered above, girth was the most important factor which governed the yieid and it was further significantly and positively correlated to the depth of tapping cut.

It was clearly evident that yicld detcrmining factors used in the present study play a major role in determining rubber yicld. Those are mainly governed by the rootstock of the plant, environment conditions and agromanagement practices. Therefore by the adaptation of the correct agromanagement practiccs and technically correct tapping, such variations within clones can be minimized and it will enhance the existing productivity levels in Sri Lanka rubber plantations.

Proceedings of the Eighth Annual Forestry and Environment Symposium 2002 of the Department of Forestry and Environmental Science, University of Sri Jayewardenepura, Sri Lanka 